Article

\title{
Contradictory and Intersecting Patterns of Inclusion and Exclusion of Street Youth in Salvador, Brazil
}

\author{
Marit Ursin \\ Norwegian Centre for Child Research, Norwegian University of Science and Technology, 7491 Trondheim, Norway; \\ E-Mail: marit.ursin@svt.ntnu.no
}

Submitted: 6 May 2016 | Accepted: 22 July 2016 | Published: 20 October 2016

\begin{abstract}
Drawing on longitudinal qualitative research in Brazil involving participant observation and narrative interviews with young homeless persons, and semi-structured interviews with middle class residents, local businesses, and patrolling police officers, three overlapping yet contradictory dimensions of inclusion and exclusion are developed. First the hegemonic exclusionary discourse that tends to produce stigmatizing labels on poor people in general, and boys and young men on the street in particular, is mapped out. Second, socio-spatial exclusionary mechanisms involving architectural measures, surveillance cameras and violent policing, guarding the neighbourhood from stigmatised 'others' are examined. Third, the less recognised but equally important inclusionary mechanisms, facilitating street life and enabling a sense of belonging among young homeless people are explored. A simplistic and unidimensional conceptualisation of social exclusion is critiqued while demonstrating the multifaceted, intertwined, and contradictory character of homeless people's social relationships with middle class residents, businesses, and police. Furthermore, the exclusion/inclusion dualism that is vivid in the existing literature is questioned. It is suggested that a nuanced picture is vital to increasing our understanding of the everyday lives of homeless populations and that further investigation and theorization of their exclusion as well as inclusion is needed.
\end{abstract}

\section{Keywords}

Brazil; homelessness; social exclusion; social inclusion; street youth

\section{Issue}

This article is part of the issue "Homelessness and Social Inclusion", edited by Isobel Anderson (University of Stirling, UK), Maša Filipovič Hrast (University of Ljubljana, Slovenia) and Joe Finnerty (University College Cork, Ireland).

(C) 2016 by the author; licensee Cogitatio (Lisbon, Portugal). This article is licensed under a Creative Commons Attribution 4.0 International License (CC BY).

\section{Introduction}

Homeless populations, particularly in the global North, have increasingly been studied and theorised through the lens of social exclusion (e.g. Horsell, 2006; Pleace, 1998; Somerville, 1998), focusing on structural exclusionary mechanisms such as unequal material distribution and discriminatory job and housing markets. Within the burgeoning literature, street dwellers are also described in terms of socio-spatial exclusion, demonstrating how they are perceived as 'unwelcome elements' in metropolitan areas in all corners of the world (e.g. Beazley, 2003; Caldeira, 2000; Scheper-Hughes, 2005; Swanson, 2007; Young, 2003). The mapping of exclusionary processes is of vital importance to unravel the dynamic as well as relational character of social exclusion of vulnerable populations. However, the unilateral focus on exclusion has rendered us incapable of recognising parallel processes of social inclusion (Cameron, 2006). In order to grasp the complexity of social exclusion, it is important to look for experiences of social inclusion among people who appear to be marginalized (Fangen, 2010), bearing in mind that the distinction between inclusion and exclusion is not sharp-cut but ambiguous (Samers, 1998).

This article is inspired by Parr's (2000) claim that ethnographic research can disrupt understandings of 'others' as homogenous individuals who are straightforwardly excluded from 'the mainstream' and moved 
into marginal spaces. Furthermore, it supports Hall's (2005) conceptualisation of social inclusion and exclusion as not absolute positions, but rather as relational and entangled in particular ways and in particular contexts. I explore the social relations between young street dwellers and middle class residents, businesses, and police in one specific neighbourhood in urban Brazil with the aim to: (1) examine the hegemonic exclusionary discourses that 'other' poor people in general and boys and young men on the street in particular; (2) map out exclusionary mechanisms that guard the socio-spatial boundaries of an elite neighbourhood; and (3) explore less known but equally important inclusionary mechanisms, facilitating street life and enabling a sense of belonging among the young homeless. Drawing on longitudinal, ethnographic research among boys and young men on the street, I document patterns of prejudice across both inclusionary and exclusionary practices. Each of the above objectives is pursued consecutively following the sections on literature review on street youth and urban space, the socio-historical contextualisation of homelessness in Brazil, and the study's methodology, to which I now turn.

\section{The Street as Site for Empowerment and Exclusion}

The geographical order of urban space is imposed mainly from 'above' by the adult dominant class, police, politicians, and city planners. Yet, young people establish parallel modes of belonging to the streets (Holloway \& Hubbard, 2001; Young, 2003). The street allows youth to contest social conventions and assert independence (Matthews, Limb, \& Taylor, 2000), and for many poor boys and young men from the deprived favelas in Brazil, the street is a site of agency and empowerment (Gough \& Franch, 2005). A growing body of research shows how young homeless populations often use 'tactics' of spatial resistance (De Certeau, 1984), encroaching upon the space of the dominating power in a language of protest, defiance, and refusal (Naterer \& Godina, 2011; Ruddick, 1998; Scheper-Hughes \& Hoffman, 1998; Young, 2003). Street youth appropriate public (as well as private) space opportunistically, using marginal spaces at marginal times (Ruddick, 1998), including spaces normally perceived as impossible, impractical, or impure by mainstream society (Young, 2003). However, studies also reveal their ambiguous position as socially marginalized yet partly accepted and incorporated in particular socio-spatial settings involving leisure or livelihood activities (Moyer, 2004; Naterer \& Godina, 2011; Ursin, 2011, 2012; Ursin \& Abebe, 2016; Young, 2003).

Young men on the street have been seen as disorderly and deviant by authorities throughout history (Pearson in Robinson, 2009), and are commonly met with 'moral panic' (Matthews et al., 2000). In the context of urban Brazil, poor young men are being scapegoated for criminal activity (Caldeira, 2000; Soares, Bill, \& Athayde, 2005). The most controversial category of young people who occupy public space is the category of 'street youth', who are positioned as an abject and dangerous underclass that poses a serious threat to the social fabric. They are commonly ignored as rights-bearing citizens in terms of public policy (Scheper-Hughes, 2005) and instead referred to in terms of culpability: 'They' cause problems for ordinary citizens, scare away tourists, and make the streets unsafe (Gaetz, 2004). Moreover, they are often described in negative and stereotypical ways in the media, public opinion, and policymaking, labelled as threatening as opposed to threatened, offenders rather than victims, and fearless instead of fearful (Pain, 2003).

As Koskela (1997) argues, fear can reflect power relations in society as a product of systematic structural violence. This fear should not be primarily interpreted as a result of factual crime but as an indicator of the power relations in which young street dwellers are embedded. Discursive exclusion is intrinsically linked with spatial exclusion, justifying and reinforcing each other (Sibley, 1995). By being constructed as a threat, marginalised young men regularly experience exclusion from both social life and urban space (Pain, 2001). Social inclusion and exclusion can therefore be understood in terms of (im)mobility, as social inclusion is a matter of overcoming spatial constraints to gain access to desired places, related to work, leisure, and social life (Cass, Shove, \& Urry, 2005). For homeless populations-who rely on public spaces to conduct essential aspects of their private lives-this access is even more crucial.

In response to the fear of crime and as a process of 'othering', society seeks to regulate public space (Koskela, 2009) through criminal justice and community safety policies, such as legal prohibitions of 'loitering', discriminatory policing, and the privatisation of public space with private security forces and close circuit television (Caldeira, 2000; Valentine, Skelton, \& Chambers, 1998). Young people who domesticate public space are often met with extreme forms of sanctioning, ranging from arrests and deportation to torture and extermination (Pain \& Francis, 2004; Ruddick, 1998; Ursin, 2012; van Blerk, 2013). Although such sanctions aim to improve the safety of some groups at the expense of others, they more often generate cumulative fear, distrust, isolation, social exclusion, and further marginalisation (Davis in Pain, 2001; Koskela, 2009; Ursin, 2012).

\section{Longitudinal Research in a Street Ambience}

Reviewing literature from the global North, Pain (2000) found that young homeless men are commonly defined as 'hard-to-reach' and regularly excluded from research on social relations in urban space, thus we know little about their experiences. To redress this, I draw on a longitudinal and ethnographic study, stretching over a decade, following the same group of boys originally inhabiting one specific neighbourhood in their transitions into adulthood. The study has a multi-method design, including participant observation, narrative interviews 
with young street dwellers, and semi-structured interviews with middle class residents, businesses, and police officers. Repetitive participant observation was employed, including participation in everyday life and indepth informal social interaction with the young people on the street, pursuing "an intimate familiarity with the 'world of the other', through getting close to the dilemmas, frustrations, routines, relationships, and risks that are a part of everyday life" (Grills, 1998, p. 4). This meant earning the young men's trust and experiencing their everyday routines of eating, sleeping, 'chasing money' (correr atras), using drugs, and hanging out. In so doing, I also managed to map interactional patterns between the street population and other users of public space.

Jackson (2002) claims that the voices of marginal groups tend to be silenced-denied public recognitiondespite their potential to enlighten new perspectives. In order to explore dimensions of social inclusion and exclusion from the 'bottom-up', I conducted narrative interviews with 14 key participants, whereof 10 engaged in two to three rounds of interviews, depending of their accessibility. The key participants were between 12 and 24 years old at the start of the study. All interviews were carried out in private at hours and in places the participants recommended, and they were given pseudonyms to protect their identities.

I also conducted interviews with middle class residents, businesses, and the police living and/or working in the chosen neighbourhood. This includes structured and open-ended interviews with 20 residents, both male and female, ranging from youth to elderly, including both users and non-users of public space; eight owners of shops, restaurants, and hotels in the neighbourhood; and the head of the neighbourhood association. In addition, I used the local newspaper as a source to increase my understanding of residents' and businesspersons' relation to public space, since letters to the editor frequently addressed neighbourhood concerns. I also carried out eight interviews with patrolling police officers (see Ursin, 2013, for a more detailed explanation on methodological and ethical issues related to the study).

\section{Social Inequality and Street Populations in Brazil}

In order to understand street populations in urban Brazil, it is necessary to trace the historical roots of contemporary social relations and the spatial segregation of Portuguese colonial rule and slavery in which the situation of homeless people is embedded. Slavery was abolished in 1888 , but Brazil failed to integrate the freed into educational and labour institutions (Risério, 2004). This resulted in an escalation of young vagrants surviving on intermittent odd jobs in the growing urban centres in the late 19th century and onwards (Fraga Filho, 1994). Post-colonial and post-slavery politics preserved social inequalities, and Brazil continued to be highly divided into hierarchical groups, situating poor, dark-skinned manual labours at the bottom of the social strata (Borges, 1992).
The European-descendent elite perceived the social mixture in the growing metropolitan areas as threatening, bringing together "an unknown and frightening demographic mixture...Amid the ostentatious display of wealth could be found all manner of people loitering about: impoverished workers, vagabonds, beggars, ruffians, prostitutes, and street urchins" (Rizzini, 2002, p. 167). Worrying about decline of urban centres, poor people's access to city centres was increasingly restricted, including through arrest orders of vagrants (Caldeira, 2000; Sangodeyi-Dabrowski, 2003). This criminalisation of the poor has marked the state's response to social problems throughout history (Fernandes, 2013). Fuelled by gentrification processes (Vaz, 1994) but also post-industrialization, rural migration, and rapid urbanization (Kenny, 2007), deprived neighbourhoods expanded in urban peripheries throughout the last century.

These neighbourhoods-today renowned as favelas-continue to expand. Wooden shacks and muddy paths have been replaced by brick houses, asphalted streets, and cemented alleys, and water, sewage, electricity, and public transportation have become easier accessible. In addition to poverty, drug cartels have a strong foothold in many of these communities, which has resulted in an alarming rate of crime, drug trafficking, and violence (Lyra, 2013; Fernandes, 2013). The country experienced a decrease in the number of families living below the poverty line during the leftist government of President Lula da Silva (2003-2011), but is currently struggling with an economic crisis and corruption scandals. School enrolment among poor children and youth has drastically increased (Bush \& Rizzini, 2011), but the public educational system is characterized by overcrowded classes, lack of resources, poorly remunerated teachers, and frequent strikes (Kenny, 2007).

The formal labour market has increased expectations in regards to educational qualifications, often demanding a minimum of completed high school (Menezes-Filho \& Scorzafave, 2009). This has led to extreme competition for job positions that require low educational levels (Barker, 2005) and an increased unemployment rate among poor youth. A quantitative study in a favela in Northeast Brazil revealed that by the age of 18 , nearly half of the residents were neither in school nor at work (Cardoso \& Verner, 2006). Livelihood possibilities are not neutral, but engender processes of inclusion and exclusion, and bureaucracy, corruption, and nepotism are common obstacles for poor young Brazilians who seek formal employment (Hecht, 1998). Many favelado youth depend on self-employment and livelihood opportunities in the informal sector (Menezes-Filho \& Scorzafave, 2009). As competition is high and purchasing power is low in their communities, many descend to wealthier areas in the city in search of income-generating opportunities (Kenny, 2007). One such area is the neighbourhood in which this study took place, where the material wealth of its middle class residents, businesses, and tourists gen- 
erates legal as well as illegal livelihood opportunities for the homeless population (Ursin \& Abebe, 2016). However, as Gough and Franch (2005) suggest, understanding the movements of young people is important to comprehend the meanings young people ascribe to urban space, the possibilities these spaces open up, and the multiple layers of social inclusion and exclusion, which will be further explored in the following sections.

\section{Creating Social Boundaries Through Processes of 'Othering'}

The site of this study - the neighbourhood of Barra-is a reference place (Jakle, Brunn, \& Roseman, 1976, p. 51), with strong symbolic value for both its middle class residents and the tourism industry. It is presented as a homogenous, clean, safe, and modern space. As places are stereotyped not only by the characteristics ascribed to them but also by the kinds of people found in them (Jakle et al., 1976), the presence of poor boys and young men working and living on the streets threatens the social status of the residents and contributes to an impression of 'social decay' (Caldeira, 2000, p. 32). One male resident (31-year-old) argued that the street population causes discomfort as it makes "the social difference visible. When you go out with your car, you don't want to see horrible things". This reveals an "out-of-sight, out-ofmind' mentality (see Swanson, 2007), emphasising the 'out-of-place-ness' as problematic instead of focusing on the root causes of homelessness-deep-seated poverty and socio-economic inequality. Entrepreneurs in tourism were often preoccupied with the foreigners' reactions, as one male hotel owner (33-year-old) explained:

"I felt embarrassed the other day when a tourist left the hotel and saw all the kids sleeping [on the pavement outside]. I called and complained to Bahiatursa [tourist department]. How can they let this happen?"

The presence of street workers was perceived as destructive to tourism, as a letter to the editor of the local newspaper demonstrates:

"It's incredible what the government allows to happen at one of the postcard images of Salvador: The lighthouse of Barra. We only see street vendors with their cool boxes...A great filth is spread throughout Barra, without anyone to inspect it or a minimum of civilization. It is impossible for Salvador to continue to be so messy, filthy, causing an awful impression on the tourists who fill the city" (A Tarde, 1 January 2009).

The letter reduces poor people's livelihoods into 'filth' and labels street vendors as dirty and uncivilised, and eliminates poor people from the status of the neighbourhood as a global tourist destination. It also shows an argumentation for state regulation and a displacement of the poor from their means of survival. This resembles the ways in which revanchist urban policies not only legitimised but also exacerbated existing socio-spatial divides in Ecuador, erasing spaces for the poor and working class while creating spaces for tourists (Swanson, 2007). As Swanson argues, while focusing on urban revitalisation to exhibit success as modern metropolises, these policies reframe persistent social problems as an issue of socio-spatial characteristics of a particular place. The street dwellers were aware of the desire to homogenise the neighbourhood, as a young man (20-year-old) said:

"There are residents who want to preserve Porto da Barra. They think about removing the street youth, making it into a world for themselves and the tourists".

Residents' and businesses' perception of the young and poor as 'out of place' buttresses on processes of 'othering', defining who belongs and who doesn't. As exclusion is "not about gradations of inequality, but about mechanisms that act to detach groups of people from the social mainstream" (Giddens, 1998, p. 104), residents and business owners continuously define and re-define the street population. This process of discursive social exclusion involves a "projection of one's own values and expectations onto the environing world" (Rapport \& Overing, 2000, p. 343). Rather than to describe and understand reality, they elaborate prejudices and eliminate ambiguities (Caldeira, 2000), attributing undesirable characteristics to the poor-boys and young men in particularto emphasise distance and difference between 'us' and 'them'. This process of 'othering' is embedded in two not mutually exclusive discourses of hygiene and urban danger as captured in the words of the president of the Residents Association when defending actions to reduce the presence of street dwellers and vendors: "We have to defend our rights to the politicians, in terms of security and sanitation".

As seen above, hygienist semantics were used to argue for the purification and beautification of urban space for the sake of tourism, describing street vendors as 'filth'. This perception was not restricted to vendors but extended to poor people in general. Many people from surrounding favelas visit this neighbourhood during weekends, enjoying the beach, play areas, and increasingly also the shopping centres. The president of the Residents Association complained about this; "On Sundays at the lighthouse, when children are playing, even the poor ones come, all dirty", continuing; "They pollute the beach. They do the necessary in the water". Thus people from the lower social strata were perceived as a polluting presence in the cityscape. The homeless population was described in even more negative terms by a male resident (25-years-old): "They incommode the tourists. They are dirty, stinking, begging, robbing". A female resident (31-year-old) complained: "the aesthetics of the neighbourhood as well, it gets ugly. [The homeless] dirty the street, litter, faeces, urine". The problem is not de- 
fined as the lack of public facilities for street dwellers and other visitors but rather how the poor contaminate the neighbourhood. The majority of the young homeless men were highly aware of the hygienist discourse, disclosing that others perceived them as germs-invading, infectious, causing diseases. This resembles the hygienist discourse that had great symbolic and political significance during the gentrification process of urban space in the late 1800s and early 1900s (Fraga Filho, 1994; Rizzini, 2002; Vaz, 1994) where poor housing complexes in downtown areas in Rio de Janeiro and São Paulo were perceived as "cooking pots for the germs of yellow fever" (Chalhoub, 1993, p. 456). The rhetorics of modernisation and urban planning echoed quests of order, sanitation, and discipline, purifying urban space. As Sibley (1995) argues, disease metaphors are common to exclusionary mechanisms since the 'diseased other' defines normality and stability. The hygienist discourse reveals a preoccupation with aesthetics based on a narrow and elitist ideal of urban space. Moreover, it also appeals to and further incites sentiments of fear with references to bacteria, disease, and pollution.

Patrolling police in Barra also drew on hygienist semantics, referring to their occasional sweeping of homeless of the street (further explained below) as 'Barra limpa', a clean Barra. By labelling someone as unclean, as imperfect members of a group, they are rendered discrepant and polluting (Douglas, 2002), not only in a literal sense but also in a symbolic sense, urging for social as well as spatial replacement. As Douglas asserts: "Dirt offends against order. Eliminating it is not a negative movement, but a positive effort to organize the environment" (p. 2). As one young street dweller (20-year-old) explained:

"The residents want to chase us out of here because they've got education, right? Many have an education, it's easier to earn money, and they will have more if we aren't around. That's why they say they want a clean Barra with Pit Bull hearts".

The sanitation of space is thus perceived as encouraging spatial order-avoiding pollution and littering-as well as social order, preserving social homogeneity. Yet there is also a dimension of morality entwined in the hygienist discourse, where middle class residents and businesspeople often described the poor as lacking educação (education)-a male resident (65-year-old) explained; "On Saturdays and Sundays less educated people come here and litter". 'Educated' is used as synonymous with the middle and upper class who are morally superior as they do not litter but take care of the environment. The Brazilian term-eduçacão-is broader than the English understanding of the word education, meaning not only to be knowledgeable and have graduated but also to be well-mannered and civilized, which reveals colonial rhetorics of certain groups as ignorant and uncivilized (Sibley, 1995).
Fear and morality are also vital components in the urban danger discourse that 'other' the poor, especially adolescent boys and young men as non-conforming and malignant. A police officer described the vital differences between rich and poor boys as following:

"A child on the street is completely different. He has a profile marked by evil, a bad person, do you understand? We know that at whatever moment he may have reactions, even of a crime of death. It's different with...the son of a rich person because we know he has education".

Likewise, a female resident (27-year-old) explained: "I would like to help them [street kids], let them live in my home, but I can't because they might kill you afterwards". This shows how young homeless men are seen as irrational, unpredictable, anti-social, and dangerous. Once again, the issue of education-or more precisely of being civilised-is accentuated. As Caldeira (2000) notes in her urban ethnography of São Paulo, poor 'others' are believed to be more vulnerable to crime and evil as they are closer to nature and irrationality. Hegemonic perceptions of poverty and crime amalgamate in Brazil as urban elites criminalize poverty by associating it with street crime and violence (Reis, 2005). Illustratively, the expression marginal-marginalized-signifies both being 'poorest of the poor' and an 'outlaw' (Perlman, 2009, p. 157). The criminalization of homelessness was reported by several young street dwellers, describing false accusations of theft and police punishment. The president of the Residents Association complained that the neighbourhood "has turned into hell. Even the car minders are thieves, they threaten to earn money, saying that they will slash your wheel". In criminalising the livelihoods of the poor, assimilating marginais, workers, and criminals, the enforcement of the class order and public order are merged (Da Matta, 1991).

Residents and business owners use their sociopolitical and economic superiority to establish young men as the society's 'other' and to ensure that stereotypes are generally accepted. In this way they legitimise the expulsion of the poor and the homeless and assert their 'rightful' belonging to the neighbourhood. Besides frequent meetings with local politicians, they talk to editors of local newspapers, expressing their concern of the presence of homeless. The president of the Residents Association was regularly in touch with the media, sometimes resulting in front-page stories such as 'The heavy Barra' (Tribunal da Bahia, 31 May 2005), accompanied by an illustration of two dark-skinned hands pointing guns towards the local light house, with the heading: "Prostitution, drugs and robberies are constant partners in a neighbourhood that used to belong to the bourgeoisie". On a discursive level, talks of urban danger and 'risk management' function as a primary mechanism of social control, excluding unwelcome people and behaviours (Fischer \& Poland, 1998). 
While discussing society's perception of young street dwellers, it became obvious that they are not only aware of their marginal status but also link it to distant social relations. One of the older men (27-year-old) living on the street reasoned: "The part of society which doesn't know me, perceive me as a marginal. I only stop being a marginal when they get to know me and see that I'm nothing like what they imagined". His street companion (27-year-old) expressed a similar view:

“Because they [the residents] don't want to know how street youth feel; what the reason behind this is, being like this; why they are going through this; what kind of difficulties they encounter. No, they don't want to know, they only want to know what they see with their eyes...They only stay at home, that's why they get this "trauma'".

By trauma, he is referring to the misconception of the street population as dangerous and the fear it causes. Another young man (20-year-old) described how the police sometimes would warn passers-by, saying that he was dangerous, lamenting: "The residents hear this from the police hence many draw their conclusions about me, totally different from who I am". When their life stories are reduced into 'a societal risk', exclusionary and discriminatory actions are stimulated and justified (Barker, 2005).

The social and spatial distance and distancing reduce possibilities of public encounters of heterogeneous groups, facilitating a lack of knowledge about 'the other'. Goldsmith's (2000) description of North American white middle class citizens is transferable to urban Brazil-they grow up in isolation, separated from others, and develop attitudes and behaviours towards African Americans that are based on simplified myths of difference, danger, and hostility rather than positive interaction. Todorov's (1992) description of the colonizer's relation to the 'other' along three axes-value judgement, rapprochement, and knowledge-helps understand middle class residents' and entrepreneurs' relation to the young street population. The moral condemnation (embedded in discourses of hygiene and danger) is allowed and sustained by distancing, which again creates and maintains ignorance, and which permits the continuance of the discourses of hygiene and urban danger. The three axes are interconnected, enabling and reinforcing each other, and maintaining a status quo of social relations in public space.

\section{Creating, Maintaining, and Reinforcing Spatial Boundaries}

Despite their superior position and their successful processes of 'othering', arguing for the expulsion of the poor and homeless in the neighbourhood, a strong sense of anxiety was observed among many residents and business owners. The president of the Residents Association was particularly explicit. She emphasized the preoccupa- tion of vanishing boundaries between the worlds of the elite and the masses, stating that "Barra has turned into the periphery". When elaborating, she explained: "Today poor people buy clothes in cheap shops that sell clothes similar to ours. They enter [into shopping centres] with tennis shoes, caps, and everything, looking like a resident, and steal everything". This reveals the apprehension and insecurity generated by social encounters between diverse groups (Wilton, 1998). Residents and businesspeople feel a continuous need to create, maintain, and reinforce social as well as spatial boundaries between them and the 'others'. In excluding the poor and the homeless from the neighbourhood, they draw on their economic resources and socio-political influence. They were fighting a losing battle in restricting the access of the poor to the neighbourhood through trying to persuade politicians to stop direct bus routes from the suburban favelas, as the president of the Residents Association explained:

"The city council said that they would only have buses from the suburbs to Lapa [the central bus station], not directly to Barra, but after the carnival he said that Lapa was nearly falling apart. They lied to gain votes. And then put up busses from far away to here".

If they had succeeded, favelado commuters would have had to pay two bus fares, which is a prohibitive cost for people with minimum wages.

A more successful approach is a costly investment in architectural measures to demarcate spatial boundaries, such as speared iron fences, broken glass cemented in the walls, electric gates and video cameras to create private and semi-private enclaves. As Caldeira (2000; see also Fischer \& Poland, 1998) writes about insular upper class spaces in São Paulo:

"These are privatized, enclosed, and monitored spaces of residence, consumption, leisure, and work. Their central justification is the fear of violent crime. They appeal to those who are abandoning the traditional public sphere of the streets to the poor, the marginalized, and the homeless" (p. 213).

Street dwellers often appropriate the interfaces between private and public spheres for sleeping, such as verandas, staircases, backyards, and garages, but such spaces are increasingly being fenced off. This not only reinforces boundaries but also makes urban space uninviting and less habitable for the homeless.

The city council also tried to make Barra less attractive for the street population. The decision to remove public benches some years ago was triggered by the presence of street youth. One street dweller (20-year-old) said:

"They removed them because there were many homeless, many street dwellers there, sleeping...And that square had to be conserved to not disrespect the 
people who wanted to stroll there and couldn't because there were many homeless there, a lot of filth".

The municipality renovated great parts of the neighbourhood in recent years, including the main boulevard and many of the squares. When discussing these changes with one of the street dwellers (27-year-old) during the last fieldwork, some of the negative consequences became evident, including a reduced sense of belonging in the neighbourhood:

"You know how we used to say that Barra was of the street people, do you remember? Today it isn't for the street people anymore. Today Barra is for the citizen, for those who have a business, a house, a home..."

He continued, elaborating on how they had lost public space to 'citizens', having fewer places to hang out due to restaurants' furnishing of the pavements, covering pavements with chairs, tables, and paying customers. As part of the revitalising of the neighbourhood, surveillance cameras were installed on street corners. This was particularly dreaded among the homeless population, as explained by a street dweller (27-year-old):

"They took away the privacy of the homeless. There isn't any privacy anymore... because they put up more security for the population, it has become more transparent. It has become more difficult for the street kids".

The transparency and the feeling of being 'watched' invaded their 'private' sphere, as the homeless tend to privatise and domesticate public space by sleeping, eating, and bathing. Furthermore, he explained that it also impeded doing drugs, having sex, and committing petty theft. Another vital change was the privatization of car parking. To mind parked cars is one of the most lucrative legal livelihoods in the city centre for street dwellers, as it does not require any equipment and has a steady flux of clients. However, during the renovation some of the streets were turned into pedestrian precincts while parking was prohibited in others, encouraging drivers to park their cars in designated, private parking lots. As a result, several young men who had worked in Barra since childhood lost their main source of income.

Surveillance cameras are not the only security measure comforting the middle class residents and local business owners. They also invest large sums on private security forces to watch entrances and patrol streets. Rigid rules are instituted, for instance making the wearing of shoes obligatory and forbidding street vendors or street people from entering. One of the older street dwellers (35-year-old), interviewed in the last fieldwork, said that:

"It has gone from bad to worse. Everyone discriminates those who live on the street, thinking that every- one who lives on the street is a thief. One cannot enter a super market because everyone is looking. The guards call the police to beat us. Often the guards, when we enter the super market to beg for something, like milk or something like that, the security guard hits us, pushes us, kicks us, pushing us out like we're dogs".

This reveals how transgressing visible and invisible boundaries is met with harsh sanctions. Many apartment buildings and business enterprises also pay the local police patrols regularly, establishing strong loyalty commitments. A male street dweller (27-year-old) reasoned:

"If you own an apartment, an apartment building, you don't want anyone to bother your clients so they leave, right? If it's the homeless who are disturbing them, what you do is pay the police to remove them, right?"

Another street dweller (24-year-old) explained that the police leave them alone if the residents approve but shoo them away if there are complaints. This reveals that even though the harshest exclusionary mechanism is often executed by the police, it is incited by the attitudes of residents and business owners.

The police do not only defend the boundaries of semiprivate and private space, but also seek to regulate and homogenize public space, pushing 'others' back to the geographical as well as social periphery. They decide who will have access to the neighbourhood through a "succession of little rituals of identification and humiliation" (Caldeira, 2000, p. 314). A police officer described how they decide who to approach; "Those who wear Mormaii, Cyclone, and Kenner [brands of clothes and sandals]. Bermuda shorts, big t-shirt, caps are characteristics of those who don't want to work, so we body search them". The style described, however, is one of the most common styles for poor youth in general, legitimizing everyday practices of discrimination and degradation of both street and favelado youth. The police draw on both the hygienist and urban danger discourse when explaining why certain groups need to be removed from the neighbourhood:

"When we appear, the neguinhos [small negros] all tremble. This place is for the tourists, right? And for the residents as well, the majority middle class. We act to guarantee the security of these people. Street youth and prostitutes need to feel fear...Hence our work is to clean this area, removing these people".

The police frequently carried out operations to deport poor young people to the outskirts of the city (see also Ursin, 2012), as one of the more seasoned street dwellers (35-year-old) described:

“You can't sleep on the street at night anymore because there are cars patrolling. If they catch you sleep- 
ing...they put you in the trunk of the car, take you to a deserted place and beat you".

Violence is also employed as a preventive strategy, as a police officer related: "[W]e beat the children and the adolescents to see if they give up hanging around here and return to the periphery". According to Wacquant (2003), Brazilian police employ a 'zero tolerance' approach, which has proved beneficial in furthering politicians' and police forces' commitment to the elimination of street crime yet is inefficient in combating actual crime. Yet, brutal-and sometimes lethal-police violence targets poor, young men as they are perceived to be the main source of deviance and violence (Caldeira, 2000; Ursin, 2012). Given the hostility of the discursive as well as the spatial exclusionary mechanisms the young people on the street encounter, it may be difficult to understand why many of them chose to remain in the neighbourhood. In the last part of the article, the subtler acts of inclusion will be explored.

\section{Subtle Acts of Social Inclusion in Everyday Encounters}

Despite many exclusionary mechanisms, there are also parallel interactional patterns, which Young (2003) defined as socio-spatial acceptance of street youth, namely 'coexistence' and 'incorporation'. As Hall (2005, p. 18) suggests, "far from being absolute positions, social inclusion and exclusion are fragmentary and relational, 'entangled' within each other in particular ways and in particular contexts". Basically, these acts facilitate survival on the street, making it easier to stay. Most importantly, as mentioned above, city centres provide livelihood opportunities that are not available in the favelas. This is often enabled by supportive social networks of mainstream citizens, also called fregueses, as a young street dweller (24-year-old) stated; "I have a lot of friendships there [on the street], who always wanted my best, gave me an opportunity" (see also Conticini, 2005; Hecht, 1998). The majority of the homeless in this study engaged in intermittent informal jobs, such as minding cars and running errands, depending on trusting social bonds-although atypical-with residents and businesspeople (Ursin, 2012). Some were also offered more stable work at hotdog stands, beach barracks, and kiosks. Thus despite experiencing social exclusion, their jobs were often more profitable than those available in the favelas, emphasizing how spatiality shapes livelihood possibilities and homeless experiences of the young men (Ursin \& Abebe, 2016).

As argued elsewhere, many of the street dwellers have lived in Barra since childhood and developed strong feelings of belonging, partly connected to their social relations with residents and business owners (Ursin, 2011). One young man described his relationship with residents as follows: "The majority is people who like me and don't speak badly about me, most of them. When I stay here [at my fixed spot] I feel at ease". A street dweller (27-yearold) who had injured his foot described how he survived on the street:

"I get by due to my friendships....II'm hungry, can you get some food for me?' Business owners, the local residents who know me since childhood. 'Damn, you know I don't like to bother people, but I need medicine'. One refuses, another gives. One refuses today but gives tomorrow".

Although there was never a guarantee of receiving help from anyone, having fregueses conquered through years of living on the street increases the chances of getting by. When poverty or indifference might encumber the help of family and friends, their extended socio-economic networks often work as much needed safety nets (Ursin \& Abebe, 2016).

Some of the interviewed residents and business owners admitted to giving food to street dwellers, either regularly or occasionally. One of the restaurant owners (49year-old) explained; "If they ask for food, I give. I do it out of pity, do you understand? Being hungry is awful". The discourse of pity is rooted in an idea of inferiority, rendering the young street dwellers as vulnerable and helpless. However, there were other reasons to donate food as well, as a female resident (38-year-old) illustrated; "When they approach me, I give [food]. But I give more out of fear than out of pity". This reveals the multifaceted and context-specific meaning of inclusionary and exclusionary processes, where even though the acts remain the same, the reasoning and rationale behind them differ. As Samers (1998) underscored, the distinction between social inclusion and exclusion is ambiguous. Although some acts increase opportunities of material inclusion (that is, access to food), they still buttress on imagined hierarchies of 'us' and 'them', regardless of whether the other is pitied or feared.

That said, inclusionary acts seem to extend beyond fear in many cases. Some residents and business owners develop individual and personal relationships with street dwellers based on mutually trust (see Ursin, 2012). These relationships facilitate the practicalities of street life in many ways besides food and money-for example, young men may use outdoor taps and store their clothes and valuables in their premises. A young man (22-yearold) who minded cars described how he used to wash the car of one of the residents and received a salary and other benefits:

"I started to keep my belongings in the apartment building of this guy, in the garage. I even had his key, 'If you need, you enter, whatever occurs you just enter into the garage'. I took baths there, changed clothes".

The motivation behind letting him use the garage might be of both altruism and self-interest as the street dweller washed his car weekly, but either way it contains a di- 
mension of social inclusion. A female resident (25-yearold) explained that she purposefully said 'good evening' to street youth hanging out in a small square close to her apartment building when she moved into the neighbourhood, hoping to ensure protection from street crime. Once again, inclusionary acts might be triggered by selfinterest, such as cheap labour and safety, rather than based on ideas of equity, equality, and dignity.

From the point of view of the street dwellers, their social networks with members of the middle class signified more than a means of survival. Being amongst 'educated' people was appreciated, as a young man (27-year-old) explained: "Here I have my best family; residents, employees who work here in Barra, several workers such as port men, security guards, taxi drivers, hotel owners, beach workers". Many of the street dwellers expressed a sense of 'being seen' by mainstream society in ways that everyday life in the favelas did not allow. This suggests that the subtler forms of inclusion occurring on the street do not only have a material dimension but also a social one.

As argued elsewhere, this feeling of 'being seen' often enabled a strengthened notion of safety on the street (Ursin, 2011). In fact, safety was one of the main reasons stated for migrating to that particular neighbourhoodan escape from domestic as well as community violence. Several argued that because of the high density of security guards and police patrols, it was difficult to commit homicide in the neighbourhood (Ursin, 2012). Many street dwellers had become acquainted with security guards working in residential or business premises, and told stories of how they keep guard over them while they sleep (Ursin, 2016) or call for help when they are injured. Others explained that the presence of the police was comforting as this reduced the chances of being attacked (Ursin, 2011). This seems odd, considering the brutal police strategies to push them back to the periphery. However, the relationship between the homeless population and the police is riddled with ambiguity, switching between protection and danger. When street dwellers befriend security guards and sleep in vicinity of the police, they capitalize on security measures financed by the middle class. This is not an inclusionary act as exclusionary discourses cause these measures in the first place. However, it demonstrates the ambiguous and complex character of social relations in terms of inclusion and exclusion.

Last but not least, these subtle acts of inclusion do not necessarily embrace all street dwellers. Through honest work, relations of inclusion and trust with the surroundings emerge (Ursin, 2014). To maintain this trust and their networks, it is crucial to avoid (visible) illegal activities, especially violence and property crime (Ursin, 2012; Ursin \& Abebe, 2016). However, as demonstrated elsewhere (Ursin, 2014), it is important to emphasize that there is no causal link between crime involvement and social exclusion. Rather, as explored in this article, social exclusion reinforces-and is reinforced by-derogatory images of public discourse, reduced le- gal livelihood possibilities, and aggressive policing, contributing to further marginalization of the homeless.

\section{Conclusions: Is There Such Thing as Social Inclusion on the Street?}

This study was based on a multi-method approach to explore the social relations between middle class residents, business owners and the police on the one hand, and poor, young men inhabiting the streets on the other. This exploration of the ways in which discursive and spatial boundaries are created and reinforced reveals a sociocultural time-lag when it comes to the processes of 'othering' the urban poor in Brazil that is rooted in colonial and post-colonial mind-sets. This othering is embedded in an enduring desire to impose a social as well as a geographical distance for the elite to be able to remain in their insular worlds. The result (and perhaps a precondition) of these 'not-in-my-backyard' practices of exclusion is that underlying social, economic, and political conditions are ignored (Fischer \& Poland, 1998) and that attempts are made to displace 'problematic' groups such as street vendors and homeless people.

The exclusionary discourses dominant among middle class residents, business owners, and police render the boys and young men on the street as dirty and dangerous. By drawing on hygienist and urban danger semantics they appeal to sentiments of fear of contamination and street crime, and ideas of superiority in terms of morality, rationality, and civility. Hegemonic discourse constructs different identities as either valued or devalued, yet it is naive to treat life as just a social construction. These discourses greatly influence the ways in which the homeless population is encountered, defined, and debated, and impacts their everyday lives and livelihoods. As Ward (2009, p. 239) reminds us; "lives are lived, experienced and enacted; people feel and respond to social constructions, whether negative or positive". The production and reproduction of difference occurs through the imposition of boundaries, which are not only social constructs of dichotomous and hierarchical relations ('us' and 'them') but also inherently spatial, directing issues of mobility, access, and expulsion. Spatial exclusion is thus both the outcome of, and integral to the production of, social difference (Wilton, 1998). Moreover, the prejudice in which exclusionary discourses is embedded is allowed and sustained by ignorance, which again is nurtured by the very same social and spatial distance and distancing it creates.

Patterns that encourage inclusion of street populations are often ignored in academic literature (Young, 2003) and the dimension of social inclusion is undertheorised in the literature on homelessness. The empirical material presented in this article reveals that despite harsh exclusionary mechanisms, such as stigmatization, hostility, and physical abuse, there are also subtle acts of acceptance and inclusion at the street level. This includes, amongst other things, greetings, food, liveli- 
hood possibilities, and protection. Although hostility towards homeless population deserves great attention, there are several implications of discounting more inclusionary dimensions of urban life. First, it reduces the so-called 'mainstream' society into homogenous populations. Second, it misrepresents social encounters across 'us' and 'them' as one-dimensional and static patterns of interaction. Third, it creates an understanding of the 'other' as homogenous social groupings who are straightforwardly excluded from 'the mainstream' to marginal spaces. Fourth, it increases incomprehension of street youth by masking reasons and rationales for remaining on the street.

An ethnographic approach is beneficial in the study of homeless people as it allows a more nuanced picture of exclusion and inclusion. The empirical material presented above reveals ambiguous patterns of social interaction and challenges the inclusion/exclusion dualism that is so present in the existing body of literature. To further unravel the complex character of these patterns, three points will be made. First, although the processes of 'othering' are fundamentally hierarchical, they may be rooted in opposing sentiments of pity and fear, which again are interlinked through the notion of inferiority. Second, both inclusionary acts - such as hand-outs and greetings-and exclusionary acts-such as beatings and physical removal-can be driven by exclusionary discourses based on the inferiority of the 'other'. This suggests that even though acts are inclusionary they are not necessarily based on ideas of equity, equality, and dignity but might be inherently instrumental. Many of these acts are vital in order to survive on the street thus highly valued by street youth. Yet, as they are embedded in diverging discourses of pity, fear, and pragmatismnot necessarily that different from the discourses that support their exclusion-it raises questions on whether all inclusion is positive, especially if the character of it and reason behind it might be exploitative and unequal. Third, inclusionary and exclusionary acts are not only imposed on street youth, but youth also actively enact and interpret them. For example, street youth capitalise on security measures financed by the middle class and businesses to exclude them to be able to feel safer and more 'at home' in the street (see also Ursin, 2011). This not only reveals the ambiguous and complex character of social relations in terms of inclusion and exclusion but also suggests limitations of the concepts of social inclusion and exclusion for being unidirectional and objectifying of the persons involved, reducing them into mere victims. In sum, this article demonstrates the multifaceted, intertwined, and contradictory character of social relations, encouraging further investigation and theorization of exclusionary as well as inclusionary mechanisms involving street dwellers.

\section{Conflict of Interests}

The author declares no conflict of interests.

\section{References}

A Tarde. (2009, January 1).

Barker, G. (2005). Dying to be men. London: Routledge.

Beazley, H. (2003) The construction and protection of individual and collective identities by street children and youth in Indonesia. Children, Youth and Environments, 13(1). Retrieved from http://colorado.edu/ journals/cye

Borges, D. (1992). The family in Bahia, Brazil, 1870-1945. Stanford: Stanford University.

Bush, M., \& Rizzini, I. (2011). Closing the gap between rights and realities for children and youth in urban Brazil: Reflections on a Brazilian project to improve policies for street children. Rio de Janeiro: CIESPI/PUC-Rio.

Cameron, A. (2006). Geographies of welfare and exclusion: Social inclusion and exception. Progress in $\mathrm{Hu}$ man Geography, 30(3), 396-404.

Caldeira, T. (2000). City of walls: Crime, segregation and citizenship in São Paulo. Berkeley: University of California.

Cardoso, A. R., \& Verner, D. (2006). School drop-out and push-out factors in Brazil: The role of early parenthood, child labor, and poverty. Bonn: IZA.

Cass, N., Shove, E., \& Urry, J. (2005). Social exclusion, mobility and access. The Sociological Review, 53(3), 539555.

Chalhoub, S. (1993). The politics of disease control: Yellow fever and race in nineteenth century Rio de Janeiro. Journal of Latin American Studies, 25(3), 441-463.

Conticini, A. (2005). Urban livelihoods from the children's perspectives: Protecting and promoting assets on the streets of Dhaka. Environment and Urbanization, $17(2), 69-81$.

Da Matta, R. (1991). Carnivals, rogues, and heroes: An interpretation of the Brazilian dilemma. Notre Dame, IN: University of Notre Dame.

De Certeau, M. (1984). The practice of everyday life. Berkeley: University of California.

Douglas, M. (2002). Purity and danger (6th ed.). London: Routledge.

Fangen, K. (2010). Social exclusion and inclusion of young immigrants: Presentation of an analytical framework. Young, 18(2), 133-156.

Fernandes, F. L. (2013). Youth gang members in Rio de Janeiro: The face of a 'lost generation' in an age of fear and mistrust. Bulletin of Latin American Research, 32(2), 210-223.

Fischer, B., \& Poland, B. (1998). Exclusion, 'risk', and social control-Reflections on community policing and public health. Geoforum, 29(2), 187-197.

Fraga Filho, W. (1994). Mendigos e vadios na Bahia do século XIX (MA thesis in history). Salvador: Universidade Federal da Bahia.

Gaetz, S. (2004). Safe streets for whom? Homeless youth, social exclusion, and criminal victimisation. Canadian 
Journal of Criminology and Criminal Justice, 46(4), 423-455.

Giddens, A. (1998). The third way: The renewal of social democracy. Cambridge: Polity Press.

Goldsmith, W. (2000). Still a global city: The racial and ethnic segmentation of New York. In P. Marcuse \& R. van Kempen (Eds.), Globalizing cities: A new spatial order? (pp. 37-55). Oxford: Blackwell.

Gough, K. \& Franch, M. (2005). Spaces of the street: Socio-spatial mobility and exclusion of youth in Recife. Children's Geographies, 3(2), 149-166.

Grills, S. (1998). Doing ethnographic research-Fieldwork settings. Thousand Oaks, CA: Sage Publications.

Hall, E. (2005). The entangled geographies of social exclusion/inclusion for people with learning disabilities. Health \& Place, 11(2), 107-115.

Hecht, T. (1998). At home in the street. Cambridge: Cambridge University.

Holloway, L., \& Hubbard, P. (2001). People and place: The extraordinary geographies of everyday life. London: Routledge.

Horsell, C. (2006). Homelessness and social exclusion: A Foucauldian perspective for social workers. Australian Social Work, 59(2), 213-225.

Jackson, M. (2002). The politics of storytelling: Violence, transgression and intersubjectivity. Copenhagen: Museum Tusculanum Press.

Jakle, J., Brunn, S., \& Roseman, C. (1976). Human spatial behaviour: A social geography. California: Duxbury Press.

Kenny, L. M. (2007). Hidden heads of households: Child labor in urban Northeast Brazil. Toronto: Broadview Press.

Koskela, H. (1997). Bold walks and breakings: Women's spatial confidence versus fear of violence. Gender, Place and Culture, 4(3), 301-319.

Koskela, H. (2009). Crime/Fear of crime. In R. Kitchin \& N. Thrift (Eds.), International Encyclopedia of Human Geography. London: Elsevier.

Lyra, D. (2013). A república dos meninos: Juventude, tráfico e virtude. Rio de Janeiro: Mauad.

Matthews, H., Limb, M., \& Taylor, M. (2000). The street as "third space." In S. Holloway \& G. Valentine (Eds.), Children's geographies: Playing, living, learning (pp. 63-79). London: Routledge.

Menezes-Filho, N., \& Scorzafave, L. (2009). Employment and inequality outcomes in Brazil. São Paulo: Insper. Retrieved from http://www.oecd.org/dataoecd/54/ 53/42546065.pdf

Moyer, E. (2004). Popular cartographies: Youthful imaginings of the global in the streets of Dar es Salaam, Tanzania. City \& Society, 16(2), 117-143.

Naterer, A., \& Godina, V. (2011). Bomzhi and their subculture: An anthropological study of the street children subculture in Makeevka, eastern Ukraine. Childhood, 18(1), 20-38.

Pain, R. (2000). Place, social relations and the fear of crime: A review. Progress in Human Geography,
24(3), 365-387.

Pain, R. (2001). Gender, race, age and fear in the city. Urban Studies, 38(5-6), 899-913.

Pain, R. (2003). Youth, age and the representation of fear. Capital \& Class, 27(2), 151-171.

Pain, R., \& Francis, P. (2004). Living with crime: Spaces of risk for homeless young people. Children's Geographies, 2(1), 95-110.

Parr, H. (2000). Interpreting the 'hidden social geographies' of mental health: Ethnographies of inclusion and exclusion in semi-institutional places. Health \& Place, 6(3), 225-237.

Perlman, J. (2009). Favela-Four decades of living on the edge of Rio de Janeiro. New York: Oxford University.

Pleace, N. (1998). Single homelessness as social exclusion: The unique and the extreme. Social Policy \& Administration, 32(1), 46-59.

Rapport, N., \& Overing, J. (2000). Social and cultural anthropology. London: Routledge.

Reis, E. (2005). Perceptions of poverty and inequality among Brazilian elites. In E. Reis \& M. Moore (Eds.), Elite perceptions of poverty and inequality (pp. 2656). London: Zed books.

Risério, A. (2004). Uma história da Cidade da Bahia. Rio de Janeiro: Versal Editores.

Rizzini, I. (2002). The child saving movement in Brazil. Ideology in the late nineteenth and early twentieth centuries. In T. Hecht (Ed.), Minor omissions: Children in Latin American history and society (pp. 165-180). Madison: University of Wisconsin.

Robinson, C. (2009). Nightscapes and leisure spaces: An ethnographic study of young people's use of free space. Journal of Youth Studies, 12(5), 501-514.

Ruddick, S. (1998). How homeless youth sub-cultures make a difference. In G. Valentine \& T. Skelton (Eds.), Cool places: Geographies of youth cultures (pp. 344362). London: Routledge.

Samers, M. (1998). Immigration, 'ethnic minorities', and 'social exclusion' in the European Union: A critical perspective. Geoforum, 29(2), 123-144.

Sangodeyi-Dabrowski, D. (2003). As raízes ideológicas da segregação no Brasil: O exemplo de Salvador. In M. Esteves Júnior \& U. Montoya Uriarte (Eds.), Panoramas urbanos: Reflexões sobre a cidade (pp. 165-184). Salvador: Edufba.

Scheper-Hughes, N. (2005). Dangerous and endangered youth: Social structures and determinants of violence. Annals of the New York Academy of Science, 1036(1), 13-46.

Scheper-Hughes, N., \& Hoffman, D. (1998). Brazilian apartheid: Street kids and the struggle for urban space. In N. Scheper-Hughes \& C. Sargent (Eds.), Small wars (pp. 352-388). Berkeley: University of California.

Sibley, D. (1995). Geographies of exclusion. London: Routledge.

Soares, L., Bill, M. V., \& Athayde, C. (2005). Cabeça do porco. Rio de Janeiro: Objetiva.

Somerville, P. (1998). Explanations of social exclusion: 
Where does housing fit in? Housing Studies, 13(6), 761-780.

Swanson, K. (2007). Revanchist urbanism heads south: The regulation of indigenous beggars and street vendors in Ecuador. Antipode, 39(4), 708-728.

Todorov, T. (1992). The conquest of America. New York: Harper Perennial.

Tribunal da Bahia. (2005, May 31).

Ursin, M. (2011). 'Wherever I lay my head is home'Young people's experience of home in the Brazilian street environment. Children's Geographies, 9(2), 221-234.

Ursin, M. (2012). 'The city is ours': The temporal construction of dominance among poor young men on the street in a Brazilian elite neighbourhood. Journal of Latin American Studies, 44(3), 467-493.

Ursin, M. (2013). 'The place where I buried my bellybutton'-A longitudinal study of transitions and belonging among young men on the street in Salvador, Brazil (PhD thesis). Bodø: University of Nordland. Available at https://brage.bibsys.no/xmlui/bit stream/id/315237/Ursin.pdf

Ursin, M. (2014). "Crack ends it all?" A study of the interrelations between crack cocaine, social environments, social relations, crime, and homicide among poor, young men in urban Brazil. Contemporary Drug Problems, 41(2).

Ursin, M. (2016). Geographies of sleep among Brazilian street youth. In K. Nairn, P. Kraftl, \& T. Skelton (Eds.), Geographies of children and young people. Space, landscape, and environment. London: Springer. Retrieved from http://link.springer.com/referencework/ 10.1007\%2F978-981-287-044-5
Ursin, M., \& Abebe, T. (2016). Young people's marginal livelihoods and social transitions in urban Brazil: A tale of four lives. In T. Abebe, J. Waters, \& T. Skelton (Eds.), Geographies of children and young people. Labouring and learning. London: Springer. Retrieved from http://link.springer.com/referenceworkentry/ 10.1007/978-981-4585-97-2_16-1

Valentine, G., Skelton, T., \& Chambers, D. (1998). Cool places: An introduction to youth and youth cultures. In T. Skelton \& G. Valentine (Eds.), Cool places: Geographies of youth cultures (pp. 1-32). London: Routledge.

van Blerk, L. (2013). New street geographies: The impact of urban governance on the mobilities of Cape Town's street youth. Urban Studies, 50(3), 556-573.

Vaz, L. V. (1994). Dos cortiços às favelas e aos edifícios de apartamentos-A modernização da moradia no Rio de Janeiro. Análise Social, xxix(3), 581-597.

Wacquant, L. (2003). Toward a dictatorship over the poor? Notes on the penalization of poverty in Brazil. Punishment \& Society, 5, 197-205.

Ward, N. (2009). Social exclusion, social identity and social work: Analysing social exclusion from a material discursive perspective. Social Work Education, 28(3), 237-252.

Wilton, R. D. (1998). The constitution of difference: Space and psyche in landscapes of exclusion. Geoforum, 29(2), 173-185.

Young, L. (2003). The 'place' of street children in Kampala, Uganda: Marginalisation, resistance, and acceptance in the urban environment. Environment and Planning D: Society and Space, 21, 607-627.

\section{About the Author}

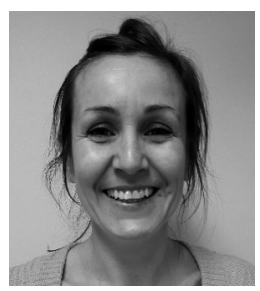

Marit Ursin is Associate Professor at the Norwegian centre for Child Research at Norwegian University of Science and Technology. She has executed a longitudinal study with young people on the verge of adulthood on the street in urban Brazil as part of her MA in anthropology and PhD in sociology. She has also worked with children in institutional settings in Brazil and Mexico, as well as explored the impact of the drug trade in poor youth's everyday lives in Brazil. 